\title{
How Do the Chinese New Farmers' Entrepreneurial Talents Drive the Business Model Innovation of Agricultural Business Organizations? Case Study Based on Grounded Research
}

\author{
Ke Zheng ${ }^{1}$, Yufeng $\mathrm{Li}^{2}$ (D) and Chaodang $\mathrm{Wu}^{3, *}$ \\ 1 School of Management, Sichuan Agricultural University, Chengdu 610065, China; 13828@sicau.edu.cn \\ 2 Department of Politics and International Relations, University of Southampton, Southampton SO16 2AA, UK; \\ y12u21@soton.ac.uk \\ 3 Faculty of Arts, Sichuan Normal University, Chengdu 610066, China \\ * Correspondence: wuchandang@163.com; Tel.: +86-139-5266-9119
}

Citation: Zheng, K.; Li, Y.; Wu, C.

How Do the Chinese New Farmers Entrepreneurial Talents Drive the Business Model Innovation of Agricultural Business Organizations? Case Study Based on Grounded Research. Businesses 2022, 2, 97-109. https://doi.org/10.3390/businesses 2010006

Academic Editor: Lester Johnson

Received: 2 February 2022

Accepted: 27 February 2022

Published: 6 March 2022

Publisher's Note: MDPI stays neutral with regard to jurisdictional claims in published maps and institutional affiliations.

Copyright: () 2022 by the authors. Licensee MDPI, Basel, Switzerland. This article is an open access article distributed under the terms and conditions of the Creative Commons Attribution (CC BY) license (https:// creativecommons.org/licenses/by/ $4.0 /)$.

\begin{abstract}
BMI in the field of agriculture has attracted more and more attention; it is argued that BMI will help in improving development quality of agricultural business sectors, as well as addressing sustainable development issues. In China's agricultural business area, the emergence of new farmers has resulted in a large number of BMI actions. This study focuses on how Chinese new-farmer entrepreneurs in the agricultural field promote the BMI of agricultural business organizations. Based on the field survey of 32 agricultural maker spaces ("maker spark") located in Sichuan Province, China, we followed the research paradigm of grounded theory. After research, we have clarified the core categories of new farmers' entrepreneurial talent and BMI-innovation behavior, respectively. The network relationship between the two groups of core categories is discussed in order to clearly identify its complex influence mechanism. This study helps us understand how agricultural entrepreneurs promote business model innovation in specific situations.
\end{abstract}

Keywords: new-farmer entrepreneurs; business model innovation; entrepreneurial talent

\section{Introduction}

It is believed that business model innovation (BMI) is an important way for business organizations to gain competitive advantage and create new value in the value network, which is supported by many empirical research [1-6]. In the field of agriculture, the BMI has also attracted much attention, especially in the area of sustainable business model innovation [7-9]. Scholars have argued that BMI will help to improve the development quality of agricultural and food economy sectors, addressing many issues, such as climate change, environmental pollution, population growth, and food security [10,11].

However, compared to other industries, especially the Internet and high-tech industry, $\mathrm{BMI}$ in the field of agricultural production and the business sector is relatively less active. The reason for this is also well understood. On the one hand, agriculture has special characteristics that are different from other industries. Obviously, the agricultural sector is constrained by a range of physical conditions, locational characteristics, and economic factors, including topography and geographic location, availability of transportation and distribution networks, proximity to markets, and labor force size and skills [12], and it is governed by a relatively independent set of policy objectives, political systems and support institutions, the political and economic environment faced by agricultural business organizations is quite different from that faced by non-farm enterprises [13], and agribusiness development often relies heavily on donated assets and natural resources [14]. On the other hand, traditional agriculture has a low level of division of labor, low marginal labor efficiency, low return on capital [15], low technicality and limited dynamism [16], low level of R\&D investment [17], strong land dependency and high pressure on resources and 
environment [18], and mature industry with limited market space expansion [14]; thus, it is often considered an area that is not conducive to growth-oriented entrepreneurial activity [19]. This means that the production and business sector of agriculture are hardly attractive to entrepreneurs seeking high growth. Furthermore, since entrepreneurs are the source of BMI, it is not surprising then that BMI in the agricultural business sector has been sluggish.

However, in China's agricultural business area, an emerging and compelling phenomenon is the emergence of a whole new group of people-who are called as new farmers. In contrast to traditional farmers, they are not the low-qualified laborers forced to stay in the countryside and engage in traditional agricultural production. Instead, they are often "newcomers" to the agricultural business area who have crossed over from other fields and seek for opportunities for high-growth oriented agricultural entrepreneurship, so they can be seen as agricultural entrepreneurs returning from the city. Among them, there are returning migrant workers, university professors and highly educated graduates with doctoral degrees, veterans, retired government officials, and other diverse groups of urban participants. New farmers are seen to be widely driving innovation in the Chinese agricultural business, because, in contrast to traditional farmers, new farmers often have a new mindset and philosophy, are familiar with Internet business models, and have a strong motivation to change the face of rural agriculture. In general, new farmers have more prominent entrepreneurial talents than traditional farmers [12,20-22].

It is due to the entry of new farmers as an advanced agricultural productive force and functioning as agricultural entrepreneurs that we have observed the emergence of a large number of innovations in production and management in the Chinese agricultural sector, e.g., Internet + agriculture, green agriculture, multi-industry integrated agriculture, etc. Furthermore, since China is promoting and implementing the development strategy of integrating the three industries, the BMI of agricultural business organizations has become a topic of great interest. Agricultural BMI is considered to help break through productionfactor constraints and cross-institutional barriers, improve resource allocation efficiency, and explore new agricultural value growth points, which is of great significance to the development of agricultural quality industries.

So, why and how can new farmers contribute to the agricultural BMI compared to traditional farmers? Specifically, what role does the entrepreneurial talents of new farmers play in this?

In fact, the facilitators and barriers of business model innovation have not been clearly answered by research in the field of strategic business management and other related academic fields, but there is no doubt that entrepreneurs play a crucial role in it [23-28].

However, most of the previous studies focus on Internet enterprises, high-tech enterprises, or start-up enterprises, and there is little research on the agricultural situation. Traditional agricultural enterprises pay attention to efficiency and cost, and the space and value of business model innovation seem to be small. However, with the rapid development of digital technology, the upgrading of agricultural consumption, the transformation of marketing mode, and people's increasing attention to food safety, the competitive situation faced by agricultural enterprises has also changed greatly, and the possibility and necessity of BMI are also increasing. Therefore, the research on the agricultural BMI is becoming more and more necessary.

Therefore, this paper focuses on how Chinese new farmers, who have outstanding entrepreneurial talents compared to traditional farmers, promote and implement BMI in the agricultural business sector. Which specific entrepreneurial talents play a key role?

To achieve the research objectives, we adopted an exploratory qualitative research method. Based on micro-cases, by diving into one after one specific micro-cases, we explore and identify the core conceptual categories of new-farmer entrepreneurial talent and identify their specific relevance to the business model innovation process. 


\section{Literature Review}

\section{1. $B M$ and $B M I$}

Business model (BM) is a new independent analysis unit to solve the unique set of problems related to value creation [23], which seems to be a concept between the focal firm and the strategic network [25]. BM can be regarded as a mechanism of value creation and income realization; the existence of the business model is to realize business value, which is the design or architecture of enterprise value creation, delivery, and acquisition mechanism $[2,4,29,30]$. The $\mathrm{BM}$ also refers to a transaction structure of stakeholders; it includes the mode of economic exchange between focus enterprises and external parties, which describes the design of transaction content, structure, and governance [23,25].

The concept of BM itself is considered to imply the connotation of BMI and represent an innovation theme [31,32]. To be specific, the BM represents a newer and more comprehensive form of cross-border organizational innovation, which complements the traditional themes of process, product, and organizational innovation, and it involves new forms of cooperation and collaboration [25,33]. BMI means the change of three dimensions: value proposition, value creation, and value acquisition [34]. It also means the change of business logic and the innovation of constituent elements or transaction relationships [4]. In addition, BMI can create a new market or carry out transaction innovation in the existing market [6].

As to the driving factors of BMI, the cognition and action of entrepreneurs play an important role. It is believed that CEOs and senior leaders might be the most important motivate force in driving BMI [35]. CEOs and senior leaders are believed to be the key decision-makers of BMI [35-37]; their experience, management mindfulness, and even leadership style will make an important influence [28,36,38].

Research in the field of entrepreneur cognition shows that entrepreneurs and nonentrepreneurs, even successful entrepreneurs and non-successful entrepreneurs, show obvious differences in the process of entrepreneurial cognition with thinking, judgment, and decision-making as the core process [39-42]. Rational cognitive factors, including knowledge structure; cognitive style; cognitive schema; and irrational factors, such as deep belief, intuitive thinking, emotion and enthusiasm, overconfidence, and so on, are believed to play an important role in entrepreneurial actions [40,41,43-45]. Therefore, entrepreneurs' cognition is an important internal source of business model innovation.

\subsection{Entrepreneurial Talent and Farmer Entrepreneurship}

Entrepreneur talent has a long-term and in-depth observation and discussion in economics. In the book Principles of Economics, Marshall called the functions of leaders, coordinators, middlemen, innovators, and uncertain risk bearers played by entrepreneurs in the process of implementation and operation as entrepreneurial talent [46]. Schumpeter especially emphasized the role of entrepreneurs' creative destruction, so entrepreneurs' talent is fully reflected in innovation [47]. Kirzner saw the unique role of entrepreneurs in exploring entrepreneurial opportunities, and believed that entrepreneurs have insight and alertness that distinguishes them from ordinary people [48]. Knight discussed the context of uncertainty and risk [49]. Mises emphasized the role of entrepreneurs in evaluating the value of resources in the unknown world in the future [50]. Therefore, in the abstract, entrepreneurial talent is a kind of competence that shows in entrepreneurs when they are introducing new value into an uncertain situation.

In fact, it has been debated whether traditional farmers can be seen as entrepreneurs and the extent to which the business activities carried out by traditional farmers can be classified as entrepreneurial in nature [12,51]. Traditional farmers are considered to be production-oriented, with a role as mere "producers" or "employees" [51,52]; thus, the traditional farmer identity seems incompatible with the concept of entrepreneur in terms of values and lifestyle [53]. However, there are many scholars who believe that there is a possibility of entrepreneurial status for farmers [12,51,54]. The need for farmers to identify and strategically plan business opportunities, create profitable businesses, and deal 
with a complex and dynamic environment in the course of their operations undoubtedly represents a component of entrepreneurial activity [12]. The study also shows that farmer entrepreneurship is more prevalent among diversified farms, large-scale farms, and fruit and vegetable growers [20-22].

With the changes in agricultural policies, the increased market orientation and integration, reduced policy subsidies, technological developments, changes in the structure of supply and demand for agricultural products, and the structural shift from productionoriented to multifunctional agriculture, the identity of farmers is also undergoing a reconfiguration $[51,52,55]$. The traditional response model oriented to scale growth and enhancing efficiency by expanding scale and strengthening specialization has become obsolete in responding to changes in consumer demand and various stakeholder demands, and it is considered to lack the spirit of innovation [56]. Farmers are encouraged to engage in commercial activities other than basic agricultural production, including non-agricultural industries, or increase the value of agricultural products through processing and direct sales [51]; farmers need to become more entrepreneurial [57].

In practice, it is also observed that farmers are becoming more entrepreneurial. On the one hand, farmer entrepreneurs expand to the field of non-agricultural entrepreneurship, such as the structural adjustment and diversification strategy of farm business, which has attracted a lot of attention $[14,15,58]$. Research on Europeans shows that farm diversification has become a strategic choice for farmers to deal with the reduction of profits and the transformation of traditional agriculture [15,59]. However, due to the lack of entrepreneurial skills, market knowledge, and network, it seems difficult for farmers to build an optimal business platform to fully realize the income potential of diversified operation [12]. On the other hand, seeking opportunities of growth-oriented agricultural entrepreneurship and the development of growth-oriented agricultural enterprises largely depend on the human capital, social capital, and the entrepreneurial ability of entrepreneurs. At the same time, the level of industry competition has an important impact [60].

\section{Research Methods and Research Process}

To avoid research distortion caused by oversimplification, we adopted a case-based qualitative research method. Compared with quantitative research, the advantage of qualitative research methods lies in the construction of a deep and thorough understanding and explanation of social phenomena [61]. Our goal was to study cases under specific micro-narrative, so that the core category and the relationship between the core categories can appear automatically.

First, we conducted grounded research to explore core categories, because grounded theory is more conducive for us to carefully investigate how new-farmer entrepreneurs carry out BMI in a specific situation. Therefore, this approach is more conducive to the exploration and analysis of the specific strategies of BMI in the unique context of China's agricultural environment. This study followed the general process of grounded research, abstracts concepts, and categories from the research text, and it further developed the relationship between categories to form a theoretical framework. Second, we adopted a network analysis method to explore the relationship between core categories. Finally, we built a theoretical framework of the mechanism of new-farmer entrepreneurs driving the BMI of agricultural business organizations based on the selective coding.

\subsection{Source of Cases}

The cases in this paper come from the field investigation of the modern Agricultural Maker Space project called "maker spark" in Sichuan Province of China. In fact, Agricultural "maker spark", known as the agricultural version of the maker space, is the attempt of new-farmer entrepreneurs to implement BMI in agricultural area. Practically, it has actually become an experimental field and innovation highland for BMI in the agricultural field. We investigated 40 registered Agricultural Maker Spaces, after removing the part with 
doubtful operating status, 32 cases were collected for our research. In the following, the names of those cases will be replaced by letters.

The text sources used are as follows:

1. Background information collected by the research team from the open media;

2. Audio recordings of in-depth interviews with the directors of the 32 operating entities of the Agricultural "maker spark" and their translation into text. Open-ended questions were used in the interview, mainly including the following: "Tell me about your process of building and operating 'maker spark'?" "What development goals and strategies have been set?" "What are your attempts and major innovations in your business model?" "What was the main difficulty facing you? How was it solved?" "What attempts have been made to address sustainability issues?", etc.;

3. The information obtained from interviews and observations made by team members; each case was assigned 3-5 investigators to form an investigation team to collect centralized information and discuss, and then reached a consensus on the investigated business model of "maker spark" and formed a descriptive text of the business model of "maker spark". Eventually, a text of about 160,000 words was formed as the basis for coding.

\subsection{Encoding Process}

Glaser and Strauss jointly created the grounded theory research method. Strauss divided the grounded theory coding into three stages: open coding, axial coding, and selective coding [62]. Open coding is the initial step of grounded theoretical analysis. Researchers classify the data from scratch. Axial coding is a process of summarizing and connecting the initial categories to further the nature and dimension of the category. It is a process of reintegrating the decomposed original data. Selective coding refers to selecting the core category, connecting with other categories, and verifying the relationship between them. In this study, according to the grounded theory and method, nvivo11 software was used as the auxiliary software in the coding process, and the core problems are naturally presented in the original materials in an open way.

\subsubsection{Open Coding of Entrepreneurial Talents of New Farmers}

Based on the independent coding of the members of the research group, the original concepts are constantly revised and adjusted through debate discussion in the group to ensure the rationality of coding. The research finally developed 208 related concepts, which were summarized and abstracted on this basis. After repeated discussion, questioning, and revision, the research team finally summarized and formed 24 categories, as shown in Table 1.

Table 1. Open coding of entrepreneurial talents of new farmers.

\begin{tabular}{|c|c|c|}
\hline \multirow{2}{*}{ Original Record } & \multicolumn{2}{|c|}{ Open Coding } \\
\hline & Conceptualization & Categorize \\
\hline $\begin{array}{l}\text { R: "The deputy head of our Township graduated } \\
\text { from the agricultural technology school. He } \\
\text { mastered the professional technology of planting } \\
\text { Ponkan. He was the chairman of Meishan science } \\
\text { and Technology Association. He led the farmers of } \\
\text { the whole township to develop Ponkan". }\end{array}$ & $\begin{array}{l}\text { Have accumulated } \\
\text { important relevant } \\
\text { entrepreneurial, } \\
\text { industrial or technical } \\
\text { experience before }\end{array}$ & $\begin{array}{l}\text { Previous } \\
\text { experience }\end{array}$ \\
\hline $\begin{array}{c}\text { Z: “I'm from Chongqing. I've known Professor } \\
\text { Peng of the citrus Institute of Southwest University } \\
\text { for a long time and have a good personal } \\
\text { relationship". }\end{array}$ & $\begin{array}{l}\text { Have important relevant } \\
\text { human contacts }\end{array}$ & $\begin{array}{l}\text { Important } \\
\text { relationship }\end{array}$ \\
\hline
\end{tabular}


Table 1. Cont.

\begin{tabular}{|c|c|c|}
\hline \multirow{2}{*}{ Original Record } & \multicolumn{2}{|c|}{ Open Coding } \\
\hline & Conceptualization & Categorize \\
\hline $\begin{array}{l}\text { Z: "Management and technology are very } \\
\text { important. In addition to the three factors I just } \\
\text { mentioned, management is too important. Many } \\
\text { others can't do it, but I know how to manage } \\
\text { it well". }\end{array}$ & $\begin{array}{l}\text { Have important } \\
\text { management skills }\end{array}$ & $\begin{array}{l}\text { Important } \\
\text { ability }\end{array}$ \\
\hline $\begin{array}{l}\text { C: "As long as you think about it, you must do it. } \\
\text { In fact, in the minds of the older generation, as } \\
\text { long as we live a good life in peace, but in our } \\
\text { young generation, we want to fight and break } \\
\text { through. As I said before, I'm a poor man. Go and } \\
\text { fight. If I succeed, I'll become a rich man. It doesn't } \\
\text { matter if I fail. Anyway, I'm also a poor man". }\end{array}$ & $\begin{array}{l}\text { Have a fighting spirit } \\
\text { that is not afraid of } \\
\text { hardship and failure }\end{array}$ & $\begin{array}{l}\text { combatant } \\
\text { spirit }\end{array}$ \\
\hline$\ldots \ldots$ & $\ldots \ldots$ & $\ldots \ldots$ \\
\hline $\begin{array}{l}\text { B: "Because I have certain resources in Mianyang } \\
\text { City, most of the time I put products on the shelves } \\
\text { that are easier to sell, and the goods are delivered } \\
\text { directly from us". }\end{array}$ & $\begin{array}{l}\text { Make full use of their } \\
\text { own resources }\end{array}$ & $\begin{array}{l}\text { Make full use } \\
\text { of resources }\end{array}$ \\
\hline
\end{tabular}

\subsubsection{Axial Coding of Entrepreneurial Talents of New Farmers}

On the basis of categorization, axial coding further develops the main category, further concretizes the attributes and dimensions of coded data categories, and then becomes a coherent and meaningful whole again. Based on the 208 concepts formed by development coding and the 24 subcategories induced and abstracted on the basis of development coding, we deeply analyzed the relationship between subcategories, reorganized the split data in open coding, and established categories. Finally, we established seven main categories, and the specific generic relationship is shown in Table 2.

Table 2. Axial coding for entrepreneurial talents of new farmers.

\begin{tabular}{|c|c|}
\hline Main Category & Subcategory \\
\hline Background features $\mathrm{AA} 1$ & $\begin{array}{l}\text { Previous experience, important relationships and } \\
\text { important abilities }\end{array}$ \\
\hline Character and attitude $\mathrm{AA} 2$ & $\begin{array}{l}\text { Fighting spirit, practical spirit, frustration response, risk } \\
\text { response, and innovation preference }\end{array}$ \\
\hline Vision and belief ${ }_{\mathrm{AA} 3}$ & $\begin{array}{l}\text { Agricultural-value identity, social-value identity, and } \\
\text { self-value identity }\end{array}$ \\
\hline Insight and judgment $\mathrm{AA}_{\mathrm{A}}$ & Opportunity insight, trend insight, and unique cognition \\
\hline Strategic planning & $\begin{array}{l}\text { Product planning, industrial development planning, key } \\
\text { technology planning, and characteristic model planning }\end{array}$ \\
\hline Innovative action $_{\mathrm{AA} 6}$ & $\begin{array}{c}\text { Marketing innovation, technological innovation, and } \\
\text { business innovation }\end{array}$ \\
\hline Resource integration action ${ }_{\mathrm{AA}}$ & $\begin{array}{c}\text { Integration and utilization of government resources, } \\
\text { construction of important cooperative relations, and full } \\
\text { utilization of self-owned resources }\end{array}$ \\
\hline
\end{tabular}

It can be seen that the entrepreneurial talents of the leaders of Agricultural Maker Space are mainly reflected in seven aspects: background characteristics, character and attitude, vision and belief, insight and judgment, strategic planning, innovative action, and resource integration. Through the exertion of their entrepreneurial talents, the "maker spark" world has formed its own unique development model in the real situation of no 
template and experience to learn from, facing resource constraints, talent shortage, and system constraints.

\subsubsection{Open Coding of BMI Activities of New Farmers}

This part of the material mainly comes from the objective operation results of the operation subject of Agricultural Maker Space. On the basis of the independent coding of the members of the research group, the original concepts are constantly revised and adjusted through debate discussion in the group to ensure the rationality of the coding. The research finally developed 41 related concepts, which were summarized and abstracted on this basis. After repeated discussion, questioning, and revision, the research team finally summarized and formed 14 categories, as shown in Table 3.

Table 3. Open coding of BMI activities of new farmers.

\begin{tabular}{|c|c|c|}
\hline \multirow{2}{*}{ Original Record } & \multicolumn{2}{|l|}{ Open Coding } \\
\hline & Conceptualization & Categorize \\
\hline $\begin{array}{l}\text { A: "Online sales through Taobao and } \\
\text { pinduoduo platforms"; }\end{array}$ & $\begin{array}{l}\text { Use the existing e-commerce platform } \\
\text { or self-built online mall }\end{array}$ & $\begin{array}{l}\text { Develop e-commerce } \\
\text { platform }\end{array}$ \\
\hline $\begin{array}{c}\text { F: "Signed supply contracts with } \\
\text { Wal-Mart and Yonghui supermarket"; }\end{array}$ & $\begin{array}{l}\text { Establish supply contracts with large } \\
\text { supermarkets }\end{array}$ & Open up key channels \\
\hline $\begin{array}{l}\text { B: Like high-end customers, it provides } \\
\text { tea tree adoption, trusteeship, picking } \\
\text { and tea customization services"; }\end{array}$ & $\begin{array}{c}\text { Provide customized services to } \\
\text { specific groups to meet personalized } \\
\text { needs }\end{array}$ & $\begin{array}{l}\text { Development } \\
\text { customization model }\end{array}$ \\
\hline $\begin{array}{l}\text { S: "Build a bamboo weaving boutique } \\
\text { for sales" }\end{array}$ & $\begin{array}{l}\text { Create a more specific sales scenario } \\
\text { with a sense of experience and value }\end{array}$ & $\begin{array}{l}\text { Increase experience } \\
\text { value }\end{array}$ \\
\hline$\cdots \cdots$ & $\ldots \ldots$ & $\ldots \ldots$ \\
\hline $\begin{array}{l}\text { A: "Making profits by providing } \\
\text { government purchase services and } \\
\text { service fees for successful projects"; }\end{array}$ & $\begin{array}{l}\text { Obtain profit sources by means of } \\
\text { incubating enterprise shares, etc. }\end{array}$ & Grinding profit mode \\
\hline
\end{tabular}

\subsubsection{Axial Coding of BMI Activities of New Farmers}

Based on the 41 concepts formed by development coding and the 14 subcategories induced and abstracted on the basis of development coding, we deeply analyzed the relationship between subcategories, reorganized the split data in open coding, and established categories. Finally, we established six main categories, and the specific generic relationship is shown in Table 4.

Table 4. Main category formed by axial coding.

\begin{tabular}{|c|c|}
\hline Main Category & Subcategory \\
\hline Value proposition innovation ${ }_{\mathrm{AA} 8}$ & Develop customized mode and increase experience value \\
\hline Value transfer innovation ${ }_{\mathrm{AA} 9}$ & Develop e-commerce platform and open up key channels \\
\hline Value production innovation ${ }_{\mathrm{AA} 10}$ & $\begin{array}{l}\text { Unify the supply of key raw materials, create a trusteeship } \\
\text { model, and develop circular economy }\end{array}$ \\
\hline Value acquisition innovation ${ }_{\mathrm{AA} 11}$ & Grinding profit mode \\
\hline Industrial value promotion $\mathrm{AA} 12_{2}$ & $\begin{array}{c}\text { Expand industrial scale, develop deep processing, build a } \\
\text { mature industrial chain, and develop the integration of three } \\
\text { industries }\end{array}$ \\
\hline Cooperative innovation ${ }_{\mathrm{AA} 14}$ & $\begin{array}{l}\text { Attach importance to group development and develop } \\
\text { multi-party cooperative relations }\end{array}$ \\
\hline
\end{tabular}

In the investigation, we found that the BMI of the agricultural "maker spark" is mainly reflected in the development of the e-commerce platform, the construction of a new marketing model, the creation of a new standardized management model, the development of new business forms, the construction of a new interest connection mechanism, etc. 


\subsubsection{Network Analysis of the Concepts of Entrepreneurial Talents and BMI Activities}

Based on the axial coding results of those two core concepts of "entrepreneurial talent and BMI activities", we calculated the matrix coding of them based the on co-occurrence frequency in those 32 cases. By analyzing the frequency of common expression of core concepts in the same frame range, we can identify the degree of correlation between concepts, and the frequency is often directly proportional to the degree of correlation between concepts. The results are shown in Table 5 .

Table 5. Matrix coding of the main category of entrepreneurial talent and BMI activities.

\begin{tabular}{|c|c|c|c|c|c|c|}
\hline & $\begin{array}{c}\text { Value } \\
\text { Proposition } \\
\text { Innovation }\end{array}$ & $\begin{array}{c}\text { Value } \\
\text { Transfer } \\
\text { Innovation }\end{array}$ & $\begin{array}{c}\text { Value } \\
\text { Acquisition } \\
\text { Innovation }\end{array}$ & $\begin{array}{c}\text { Value } \\
\text { Production } \\
\text { Innovation }\end{array}$ & $\begin{array}{c}\text { Industrial } \\
\text { Value } \\
\text { Promotion }\end{array}$ & $\begin{array}{l}\text { Cooperative } \\
\text { Innovation }\end{array}$ \\
\hline Background features & 3 & 16 & 13 & 3 & 10 & 2 \\
\hline Character and attitude & 0 & 15 & 18 & 6 & 12 & 3 \\
\hline Vision and belief & 3 & 11 & 11 & 6 & 7 & 3 \\
\hline Insight and judgment & 6 & 18 & 22 & 4 & 16 & 11 \\
\hline Strategic planning & 2 & 13 & 23 & 9 & 15 & 6 \\
\hline Innovative action & 5 & 14 & 14 & 7 & 3 & 3 \\
\hline Resource integration action & 5 & 11 & 13 & 17 & 6 & 5 \\
\hline
\end{tabular}

Note: the scope of interaction used in this paper appears in the same material.

This matrix forms a 2-module network. First, we transform it into a 1-modular network based on minimums method. Then we get the entrepreneur talent 1-module matrix and business model innovation 1-module matrix, respectively. Based on these two matrices, a group analysis based on centrality is carried out; the results are shown in Figures 1 and 2 below.

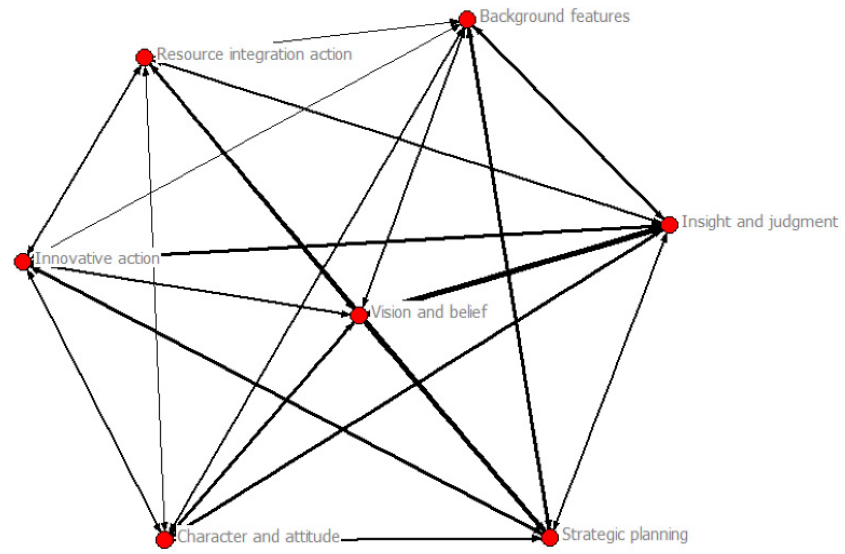

Figure 1. Group analysis of main category of entrepreneurial talent.

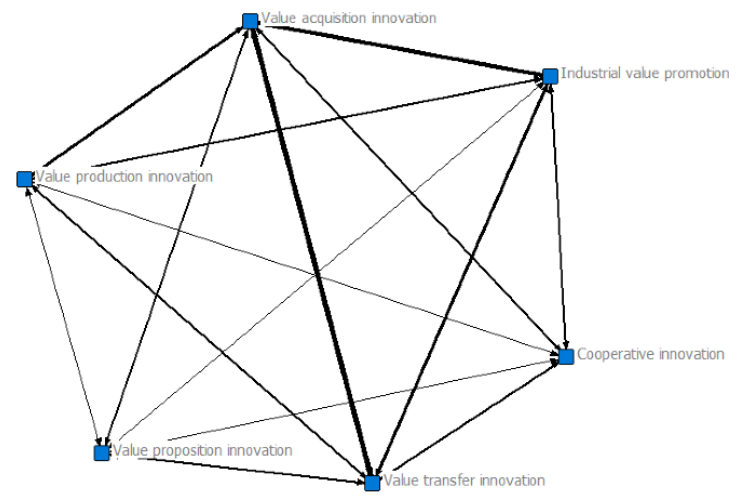

Figure 2. Group analysis of main category of BMI. 
As shown in Figure 1, the most central concept of entrepreneurial talent is vision and belief, and then insight and judgment, strategic planning, and recourse integration action have a close relation to it. In Figure 2, we can see the close relation between value acquisition and value transfer innovation.

Based on the analysis of the centrality of the 2-module matrix formed by "entrepreneurial talent-business model innovation", we can draw the relationship network as shown in Figure 3 below.

From the network analysis results, we can clearly see the interaction between entrepreneurial talent and BMI. For example, insight and judgment plays an important role in promoting value acquisition and innovation and in industrial value promotion, as well as in value transfer innovation. This means that entrepreneurs' unique opportunity insight, trend insight, and unique cognition are significantly reflected in the construction of new production mode, the expansion of value channels, and the expansion of the overall value of the industry.

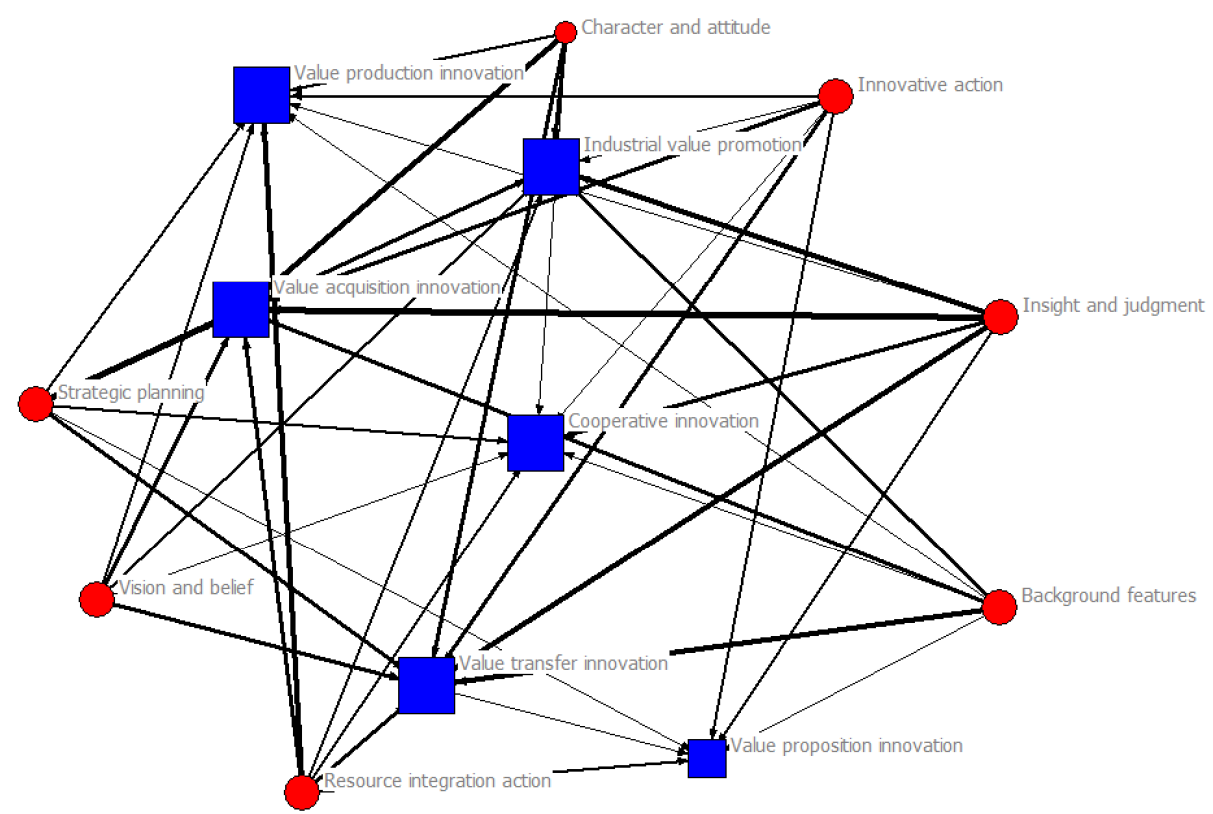

Figure 3. Relationship network "entrepreneurial talent-business model innovation".

\subsubsection{Selective Coding}

Selective coding is used to analyze and deal with the relationship between categories and synthesize and further excavate the core categories, so as to lay the foundation for the construction of the theoretical framework. According to the research progress of entrepreneur talent theory, we find that the main category of entrepreneur talent actually fully reflects the entrepreneur's personal characteristics (background characteristics, character, and attitude), cognitive characteristics (vision and belief, insight and judgment, and strategic planning), and behavior orientation (innovation action and resource integration action). The main category of business model innovation actually focuses on two main dimensions, namely the value dimension and cooperative transaction dimension, which also fully reflect the most important value perspective and transaction perspective of the business model. Combining the entrepreneur talent theory and business-model innovation theory, we put forward the conceptual model of the mechanism of new-farmer entrepreneurs drive the BMI of agricultural business organizations, shown in Figure 4. 


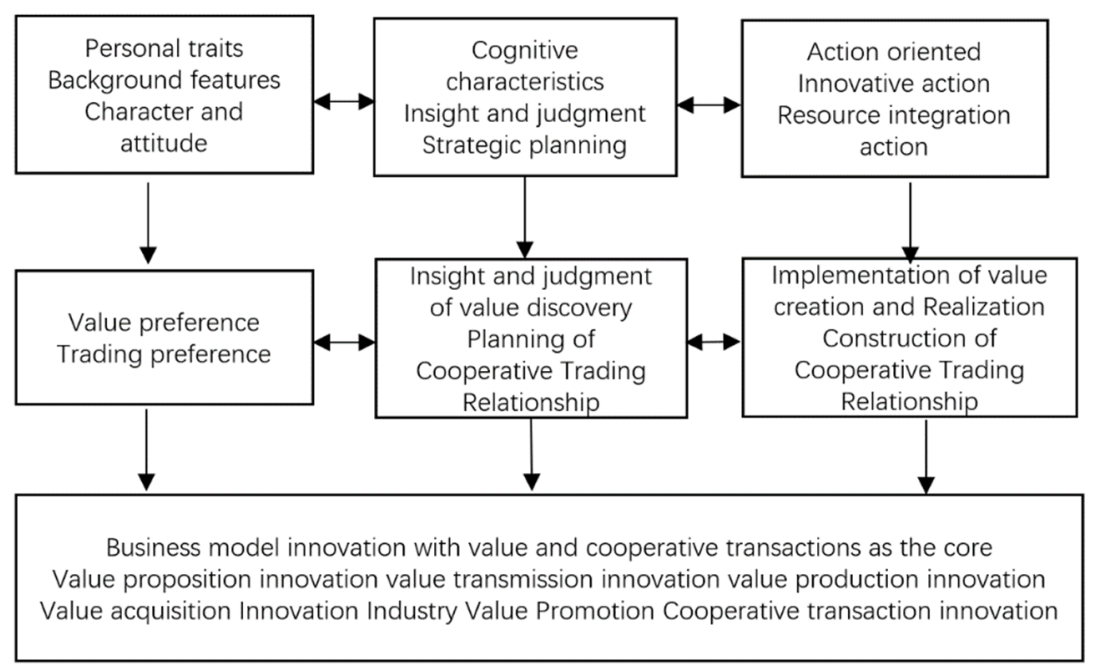

Figure 4. Conceptual model of the mechanism of new-farmer entrepreneurs drive the BMI of agricultural business organizations.

\subsubsection{Theoretical Saturation Test}

Theoretical saturation means that there are no new concepts, categories, or relationships in new data, and the abstracted concepts or categories in the research are enough to cover the data collected by researchers and even new data. The research team consists of $3-5$ people and is divided into seven groups. They adopt the method of coding separately, and then conduct joint discussion and coding verification to ensure that no category is omitted and reach the theoretical saturation.

\section{Discussion}

This paper focused on how new farmers, a new group of agricultural entrepreneurs in China, who have outstanding entrepreneurial talents compared to traditional farmers, promote and implement the BMI in the agricultural business sector through their unique cognition and action.

To achieve the research objectives, we adopted the grounded research paradigm. We collected 32 cases after visiting and investigating 40 Agricultural Maker Space in Sichuan Province. Based on these materials, we first identified concepts from materials through open coding and axial coding and categorized the core concepts. Then we used network analysis to study the relationship between core categories. Finally, we used selective coding to construct the conceptual framework of the topics discussed in this paper.

In detail, we identified seven core categories of entrepreneurial talents, which are background features, character and attitude, vision and belief, insight and judgment, strategic planning, innovative action, and resource integration action. The results of our conceptual network analysis show that the most central concept of entrepreneurial talent is vision and belief, and then insight and judgment, strategic planning, and recourse integration action have a close relation to it. There is a close interaction between categories. Together, they constitute the representation system of entrepreneurial talents.

We also identified six core categories of BMI, which are value proposition innovation, value transfer innovation, value acquisition innovation, value production innovation, industrial value promotion, and cooperative innovation.

Furthermore, through the relationship network analysis of "entrepreneurial talentbusiness model innovation", we can clearly see how the core category of entrepreneurial talent can jointly promote the occurrence of BMI.

Logically, the "cognition and action" of entrepreneurs is the internal driving force of BMI. An entrepreneur's ability consists of that entrepreneur's cognition and action, and the entrepreneur's cognition takes personal characteristics as the leading factor. Under the restriction of experience, ability and social network embedded, entrepreneurs form a 
strong concrete cognition of hard-work spirit, practical spirit, innovation spirit, opportunity consciousness, frustration- and risk-response consciousness, and strong social entrepreneurship intention. On this basis, facing the multiple constraints of different natural resources, lack of human capital, characteristics of agricultural technology and agricultural industry, and not greatly affected by government actions and policies, entrepreneurs' actions are experimental and a trial-and-error process represented by the integration of resources, strategic planning, and innovative actions.

BMI focuses on the two core dimensions of "value" and "cooperative transaction". The business model itself exists to realize the business value, which is realized by the whole process of value proposition, value production and transmission, industrial value promotion, and value acquisition. The of Agricultural Maker Space makes full use of its own endowment advantages; it is developing towards the direction of high added value and low difficulty in model promotion, as well as providing a complete set of solutions. The industrial scale is expanded, the industrial chain is extended, and the integration model of three industries is constantly being explored.

Entrepreneurs can drive business model innovation through "personal characteristics cognitive characteristics action orientation". According to the matrix code of the main category of entrepreneurial talent and the main category of BMI, entrepreneurial talent has a general impact on business model innovation, and different types of entrepreneurial talents have different effects on different business model innovation. The difference of entrepreneurs' personal characteristics will lead to the difference between entrepreneurs ${ }^{\prime}$ preference for value and transaction. The cognitive characteristics of entrepreneurs will affect the insight of value discovery and the planning of the cooperative trading relationship. Different action orientations of entrepreneurs will have an impact on the creation and implementation of enterprise value and the construction of cooperative trading relationship. Personal characteristics, cognitive characteristics, and action orientations together constitute the overall path. As a result, business model innovation centered on value-based cooperative transactions is promoted.

\section{Conclusions}

This study focused on how new-farmer entrepreneurs in the agricultural field promote the BMI of agricultural business organizations. In order to achieve the research goal, we conducted a detailed field investigation on 32 new agricultural business organizations in China.

We followed the research paradigm of grounded theory. After the research, we clarified the core categories of new farmers' entrepreneurial talent and business model innovation behavior, respectively. Based on this, the interactive network relationship between the two groups of core categories was discussed in order to clearly identify its complex influence mechanism. Therefore, from the perspective of micro-narration, we can clearly express answers to the following questions: What is the entrepreneurial talent of new farmers' entrepreneurs? How do these talents promote business model innovation?

Our research is based on an in-depth observation of a new phenomenon, that is, the business model innovation actions of Chinese new-farmer entrepreneurs in the field of agriculture business. Our case-based study showed, in detail, how new farmers and entrepreneurs can promote BMI. Our research contributes to the in-depth discussion of the new-farmer phenomenon and the understanding of the BMI mechanism.

Author Contributions: K.Z. conceived and designed the experiments and wrote the paper; Y.L. performed the experiments and contributed the reagents and analysis tools; C.W. provided the funds. All authors have read and agreed to the published version of the manuscript.

Funding: This work was supported by Sichuan Science and Technology program (2019JDR0037).

Institutional Review Board Statement: Not applicable.

Informed Consent Statement: Informed consent was obtained from all subjects involved in the study. 


\section{Data Availability Statement: Not applicable.}

Conflicts of Interest: The authors declare no conflict of interest.

\section{References}

1. Christensen, C.M. Competitive advantage. Mit Sloan Manag. Rev. 2001, 42, 105-109.

2. Osterwalder, A. The Business Model Ontology a Proposition in a Design Science Approach. Ph.D. Thesis, Faculté des Hautes Etudes Commerciales, Université de Lausanne, Lausanne, Switzerland, 2004.

3. Zott, C.; Amit, R. The fit between product market strategy and business model: Implications for firm performance. Strateg. Manag. J. 2008, 29, 1-26. [CrossRef]

4. Teece, D.J. Business models, business strategy and innovation. Long Range Plan. 2010, 43, 172-194. [CrossRef]

5. $\mathrm{Hu}, \mathrm{B}$; C Chen, W. Business model ambidexterity and technological innovation performance: Evidence from China. Technol. Anal. Strateg. Manag. 2016, 28, 583-600. [CrossRef]

6. Zott, C.; Amit, R. Business model design and the performance of entrepreneurial firms. Organ. Sci. 2007, 18, 181-199. [CrossRef]

7. Kähkönen, A.K. Value net-A new business model for the food industry? Br. Food J. 2012, 114, 681-701. [CrossRef]

8. Tell, J.; Hoveskog, M.; Ulvenblad, P.; Ulvenblad, P.O.; Barth, H.; Ståhl, J. Business model innovation in the agri-food sector: A literature review. Br. Food J. 2016, 118, 1462-1476. [CrossRef]

9. Zecevic, M.; Pezo, L.; Bodroza-Solarov, M.; Brlek, T.; Krulj, J.; Kojić, J.; Marić, B. A business model in agricultural production in Serbia, developing towards sustainability. Економика Пољопривреде 2019, 66, 437-456. [CrossRef]

10. Nosratabadi, S.; Pinter, G.; Mosavi, A.; Semperger, S. Sustainable banking; evaluation of the European business models. Sustainability 2020, 12, 2314. [CrossRef]

11. Franceschelli, M.V.; Santoro, G.; Candelo, E. Business model innovation for sustainability: A food start-up case study. Br. Food J. 2018, 120, 2483-2494. [CrossRef]

12. Mcelwee, G. A taxonomy of entrepreneurial farmers. Int. J. Entrep. Small Bus. 2008, 6, 465-478. [CrossRef]

13. Phillipson, J.; Gorton, M.; Raley, M.; Moxey, A. Treating farms as firms? The evolution of farm business support from productionist to entrepreneurial models. Environ. Plan. C Gov. Policy 2004, 22, 31-54. [CrossRef]

14. Grande, J. New venture creation in the farm sector-critical resources and capabilities. J. Rural. Stud. 2011, 27, 220-233. [CrossRef]

15. McNally, S. Farm diversification in England and Wales-what can we learn from the farm business survey? J. Rural. Stud. 2001, 17, 247-257. [CrossRef]

16. Lans, T.; Seuneke, P.; Klerkx, L. Agricultural entrepreneurship. Encycl. Creat. Invent. Innov. Entrep. 2020, 43-49. [CrossRef]

17. Roucan-Kane, M.; Gray, A.W.; Boehlje, M. Approaches for selecting product innovation projects in US food and agribusiness companies. Int. Food Agribus. Manag. Rev. 2011, 14, 51.

18. Dias, C.S.; Rodrigues, R.G.; Ferreira, J.J. Agricultural entrepreneurship: Going back to the basics. J. Rural Stud. 2019, 70, 125-138. [CrossRef]

19. Fitz-Koch, S.; Nordqvist, M.; Carter, S.; Hunter, E. Entrepreneurship in the agricultural sector: A literature review and future research opportunities. Entrep. Theory Pract. 2018, 42, 129-166. [CrossRef]

20. Gonzales, J.J.; Benito, C.G. Profession and identity. The case of family farming in Spain. Sociol. Rural. 2001, 41, 343-357. [CrossRef]

21. Vesala, K.; Peura, J.; McElwee, G. The split entrepreneurial identity of the farmer. J. Small Bus. Enterp. Dev. 2007, $14,48 \mathrm{e} 63$.

22. Shucksmith, M.; Herrmann, V. Future changes in British agriculture: Projecting divergent farm household behaviour. J. Agric. Econ. 2002, 53, 37-50. [CrossRef]

23. Amit, R.; Zott, C. Value creation in e-business. Strateg. Manag. J. 2001, 22, 493-520. [CrossRef]

24. Brynjolfsson, E.; Hitt, L. Intangible assets and the economic impact of computers. In Transforming Enterprise: The Economic and Social Implications of Information Technology; Dutton, W., Kahin, B., O'Callaghan, R., Wyckoff, A., Eds.; MIT Press: Boston, MA, USA, 2004; pp. 27-48.

25. Zott, C.; Amit, R.; Massa, L. The business model: Recent developments and future research. J. Manag. 2011, 37, $1019-1042$.

26. Spieth, P.; Schneckenberg, D.; Matzler, K. Exploring the linkage between business model (\&) innovation and the strategy of the firm. RED Manag. 2016, 46, 403-413.

27. Casadesus-Masanell, R.; Ricart, J.E. How to design a winning business model. Harv. Bus. Rev. 2011, 89, $100-107$.

28. Bhatti, S.H.; Santoro, G.; Khan, J.; Rizzato, F. Antecedents and consequences of business model innovation in the IT industry. J. Bus. Res. 2021, 123, 389-400. [CrossRef]

29. Richardson, J. The business model: An integrative framework for strategy execution. Strateg. Chang. 2008, 17, 133-144. [CrossRef]

30. Baden-Fuller, C.; Mangematin, V. Business models: A challenging agenda. Strateg. Organ. 2013, 11, 418-427. [CrossRef]

31. Spieth, P.; Schneckenberg, D.; Ricart, J.E. Business model innovation-state of the art and future challenges for the field. RED Manag. 2014, 44, 237-247.

32. Mitchell, D.; Coles, C. The Ultimate Competitive Advantage: Secrets of Continually Developing a More Profitable Business Model; Berrett-Koehler Publishers: Oakland, CA, USA, 2003.

33. Foss, N.J.; Saebi, T. Fifteen years of research on business model innovation: How far have we come, and where should we go? J. Manag. 2017, 43, 200-227. [CrossRef] 
34. Clauss, T. Measuring business model innovation: Conceptualization, scale development, and proof of performance. RED Manag. 2017, 47, 385-403.

35. Chesbrough, H. Business model innovation: Opportunities and barriers. Long Range Plan. 2010, 43, 354-363. [CrossRef]

36. Child, J.; Hsieh, L.; Elbanna, S.; Karmowska, J.; Marinova, S.; Puthusserry, P.; Tsai, T.; Narooz, R.; Zhang, Y. SME international business models: The role of context and experience. J. World Bus. 2017, 52, 664-679. [CrossRef]

37. Lindgren, P. Business model innovation leadership: How do SME's strategically lead business model innovation? Int. J. Bus. Manag. 2012, 7, 53. [CrossRef]

38. Colovic, A. Leadership and business model innovation in late internationalizing SMEs. Long Range Plan. 2021, 55, 102083. [CrossRef]

39. Casson, M.; Godley, A. Revisiting the emergence of the modern business enterprise: Entrepreneurship and the Singer global distribution system. J. Manag. Stud. 2007, 44, 1064-1077. [CrossRef]

40. Mitchell, R.K.; Busenitz, L.; Lant, T.; McDougall, P.P.; Morse, E.A.; Smith, J.B. Toward a theory of entrepreneurial cognition: Rethinking the people side of entrepreneurship research. Entrep. Theory Pract. 2002, 27, 93-104. [CrossRef]

41. Krueger, N.F. The cognitive infrastructure of opportunity emergence. In Entrepreneurship; Springer: Berlin, Germany, 2007; pp. 185-206.

42. Foss, N.J.; Klein, P.G. Stakeholders and corporate social responsibility: An ownership perspective. In Sustainability, Stakeholder Governance, and Corporate Social Responsibility; Emerald Publishing Limited: Bingley, UK, 2018.

43. Busenitz, L.; Barney, J. Differences between Entrepreneurs and Managers in Large Organizations: Biases and Heuristics in Strategic Decision-Making. J. Bus. Ventur. 1997, 12, 9-30. [CrossRef]

44. Baron, R.A. Cognitive mechanisms in entrepreneurship: Why and when enterpreneurs think differently than other people. J. Bus. Ventur. 1998, 13, 275-294. [CrossRef]

45. Simon, M.; Houghton, S.M.; Aquino, K. Cognitive biases, risk perception, and venture formation: How individuals decide to start companies. J. Bus. Ventur. 2000, 15, 113-134. [CrossRef]

46. Marshall, A. Principles of Political Economy; Maxmillan: New York, NY, USA, 1890.

47. Schumpeter, J. The Theory of Economic Development; Transaction Publishers: Piscataway, NJ, USA, 1982.

48. Kirzner, I.M. The alert and creative entrepreneur. Small Bus. Econ. 2009, 32, 145-152. [CrossRef]

49. Knight, F. Risk, Uncertainty and Profit; Hart, Schaffner \& Marx; Houghton Mifflin: Boston, MA, USA, 1921. Available online: http:/ / www.econlib.org/library/Knight/knRUP.html (accessed on 1 February 2022).

50. Mises, L.V. Human Action; Ludwig von Mises Institute: Auburn, AL, USA, 1998.

51. Vesala, H.T.; Vesala, K.M. Entrepreneurs and producers: Identities of Finnish farmers in 2001 and 2006. J. Rural. Stud. 2010, 26, 21-30. [CrossRef]

52. Burton, R.J.F.; Wilson, G.A. Injecting social psychology theory into conceptualisations of agricultural agency: Towards a postproductivist farmer selfidentity? J. Rural. Stud. 2006, 22, 95-115. [CrossRef]

53. Katila, S. Maanviljelija Perheiden Selviytymisstrategiat (Coping Strategies of Farm Families). 2001. Available online: www. yrittajakoulu.com/yrittajyydenn_oppia/dokumentit (accessed on 12 November 2007).

54. Bryant, L. The detraditionalization of occupational identities in farming in South Australia. Sociol. Rural. 1999, 39, 236-261. [CrossRef]

55. Potter, C.; Tilzey, M. Agricultural policy discourses in the European post-Fordist transition: Neoliberalism, neomercantilism and multifunctionality. Prog. Hum. Geogr. 2005, 29, 581-600. [CrossRef]

56. De Lauwere, C.C. The role of agricultural entrepreneurship in Dutch agriculture of today. Agric. Econ. 2005, 33, 229-238. [CrossRef]

57. Morgan, S.L.; Marsden, T.; Miele, M.; Morley, A. Agricultural multifunctionality and farmers' entrepreneurial skills: A study of Tuscan and Welsh farmers. J. Rural Stud. 2010, 26, 116-129. [CrossRef]

58. Meert, H.; van Huylenbroeck, T.; Bourgeois, M.; van Hecke, E. Farm Household survival strategies and diversification on marginal farms. J. Rural. Stud. 2005, 21, 81-97. [CrossRef]

59. Carter, S. Multiple business ownership in the farm sector: Assessing the enterprise and employment contributions of farmers in Cambridgeshire. J. Rural. Stud. 1999, 15, 417-429. [CrossRef]

60. Pindado, E.; Sánchez, M. Growth-oriented new agricultural ventures: The role of entrepreneurial resources and capabilities under convergence forces. Eur. Rev. Agric. Econ. 2019, 46, 800-833. [CrossRef]

61. Chen, X.M. From one to all: The generalizability of qualitative research. Educ. Res. Exp. 2000, 2, 1-7.

62. Strauss, A.; Corbin, J. Basics of Qualitative Research: Grounded Theory Procedures and Techniques; SAGE Publications: Thousand Oaks, CA, USA, 1990. 